\title{
The Splendour of Negation: R. S. Bhatnagar Revisited with a Buddhist Tinge
}

\section{D. Sebastian ${ }^{1}$ (1)}

Received: 4 April 2019 / Revised: 24 April 2020 / Accepted: 13 July 2020 / Published online: 25 July 2020 (C) ICPR 2020

\begin{abstract}
Negation has occupied a unique place in the history of ideas. Negation as opposed to truth-conditional affirmation has been very much present in Indian and Western thought from very early times. R. S. Bhatnagar of happy memory (1933-2019) in his "Many Splendoured Negation" (Bhatnagar in J Indian Counc Philos Res XXII(3):83-906, 2006) had shown many a facet that could be construed in "negation". This paper is an attempt to revisit the notion of negation that R. S. Bhatnagar brought to light and to further the germane thought that he had outlined in his concise exposé. Though Bhatnagar had stated that there could be negative and positive functions of negations, a vigilant reading of his article shows that the primary import of Bhatnagar is to examine the positive function of negation. According to R. S. Bhatnagar, even death, which could be the negative in its most feared form, the reality of which, has the positive effect on the soul force in its commitment to live well and die well. R. S. Bhatnagar's engagement with negation is not complete unless one takes into consideration "negation" as an integral part of philosophizing in India, whether it is the Buddhist tradition or any other tradition. One encounters the philosophical "exercise" on negation enormously in Buddhist thought. The first part of the paper is a brief discussion on the views of Bhatnagar in his essay mentioned with the author's considerable add-on, while the second part brings home the Buddhist facet and paradigm of negation, the missing link in Bhatnagar. The third part of the paper is an unveilment of the cogitation of R. S. Bhatnagar on "death" in terms of negation.
\end{abstract}

Keywords Bhatnagar $\cdot$ Buddhism $\cdot$ Death $\cdot$ Dialectics $\cdot$ Mādhyamika $\cdot$ Negation

Negation has occupied a unique place in the history of ideas. "Negation is one of the most primitive elements of human thought. There is no language without symbols,

C. D. Sebastian

Sebastian@iitb.ac.in

1 Philosophy Group, Department of Humanities and Social Sciences, Indian Institute of Technology Bombay, Mumbai 400076, India 
like no, not, none, etc. There is no system of logic, mathematics, science, philosophy or theology in which negation does not play a fundamental role. Generally speaking, no system, i.e. a coherent series of propositions referring to a specific subject, is possible without it, because its omission would destroy this very coherence" (Heinemann 1943-1944: 127). R. S. Bhatnagar" in his "Many Splendoured Negation" (Bhatnagar 2006: 83-90) had shown many a facet that could be construed in "negation". This paper is an attempt to revisit notion of negation that R. S. Bhatnagar brought to light, and to further the germane thought that he had outlined in his concise exposé. Though Bhatnagar had stated that there could be negative and positive functions of negations, a vigilant reading his article shows that the primary import of Bhatnagar is to examine the positive function of negation. Even death, which could be the negative in its most feared form, the reality of which, has the positive effect on the soul force in its commitment to live well and die well (Bhatnagar 2006: 90). The first part of the paper is a brief discussion on the views of Bhatnagar in his essay mentioned with this present author's add-on, while the second part brings home the Buddhist facet and paradigm of negation, the missing link in Bhatnagar. The third part of the paper is an unveilment of the cogitation of R. S. Bhatnagar on "death".

\section{The Splendour of Negation}

An attentive reading of R. S. Bhatnagar's "Many Splendoured Negation" (Bhatnagar 2006: 83-90) opens up to the reader a gamut his cogitations on negation. "Negation" as opposed to truth-conditional affirmation has been very much present in Indian and Western thought from very early times. Buddhism and Advaita are known for their predisposition to negation while philosophizing, whether in epistemology or metaphysics (Tripathi 1977: 345-355). Negation tracks and brightens the major developments in the history of metaphysics, epistemology, logic, philosophy of language and philosophy of mind. In the history of thought, Parmenides, Plato and Aristotle through Frege, Russell, and Wittgenstein to contemporary formal theorists, all have taken recourse to negation in one way or other (Speranza and Horn 2010: 277-301). "Negation is a natural foregrounding device typically used in discourse to deny a previous proposition that is explicitly mentioned or implicit in previous discourse. This process typically involves the defeat of an expectation" (Downing 2000: 197). This defeat of the expectation in affirmation is the hallmark of negation, as "every affirmative determination implies negation" (Heinemann 1943-1944: 152). Further, "negation is something that we do. It is typically a judgment that we

\footnotetext{
1 Rajendra S. Bhatnagar (01 January 1933-06 November 2019), obtained his doctorate from the University of Allahabad (in 1959), taught philosophy at University of Rajasthan, Jaipur. He was a close associate and friend of Daya Krishna. He wrote extensively on philosophical issues, especially in Hindi, and among them the notable are his eighty papers and ten books. The author of this article would like to pay his respects and homage to Professor R. S. Bhatnagar through this paper. The author cherishes their friendship, and treasure the time R. S. Bhatnagar and the author spent in discussing philosophy and Buddhist thought (the last sentence was added after getting the reviews).
} 
make, a judgment that something is not the case, and it usually-albeit by no means exclusively-takes the form of a statement" (Dahlstrom 2010: 247). As F. H. Heinemann had opined "negation occupies, moreover, a unique position in human knowledge and in the history of human thought as being the only topic on which Dogmatists and Sceptics agree. Indeed, every proposition of the Dogmatists, including the so-called laws of thought, like principle of identity, the laws of contradiction and of excluded middle, the principle of sufficient reason, and its application, the law of causality, have been rejected at one time or another. But the principle of negation cannot be denied because this very denial would postulate that principle which it tries to ignore" (Heinemann 1943-1944: 127).

The positive function of negation is what R. S. Bhatnagar is mainly concerned in his succinct essay that is under discussion. He states at the outset itself that negation is "operative in diverse domains such as ontological, epistemic, ${ }^{2}$ evaluative and creative" (Bhatnagar 2006: 83). And the implications of the negation are "noticed most often in rejection, destruction, violence, evil, dread and death" (Bhatnagar 2006: 83). And he would argue that there could be a "positive and creative role" of negation, and that has not got the attention it should have got in philosophy as "their positive and creative role does not seem to be so obvious" (Bhatnagar 2006: 83). There is a creative role of negation. As Alain Badiou says: "if we have the means to really negate the established order-in the moment of that sort of negation-there is the birth of the new order" (Van Houdt 2011: 234). R. S. Bhatnagar's entire enterprise in the succinct paper is to look at this "positive" role, as he says: "The positive roles attract attention and the following exercise is the consequence of this attraction" (Bhatnagar 2006: 83). In the following, I make an attempt to pinpoint three main areas to which R. S. Bhatnagar's engagement with "negation" could be laid bare.

\section{Negation and Epistemology}

R. S. Bhatnagar is an intense epistemologist as one could see epistemic paradigms were put to test in his writings. Discussing the cognitive and epistemic process, R. $\mathrm{S}$. Bhatnagar would say that there is a role of negativity involved in cognitive process which enables a thought process in the desired way. He says: "A more important role of negativity is to be noticed in the very process of cognitive enterprise. ... They (cognitive processes) necessitate rejection, modification, subtractions and additions and so on. True and false, right and wrong, good and bad, proper and improper are all evaluative categories which serve as sifting pointers. Unless negativity is accepted as operative in these cognitive activities and processes, thought would just not move" (Bhatnagar 2006: 85). Any cognitive process is an assertion or

\footnotetext{
${ }^{2}$ Is negation ontological or epistemological? As Dhirendra Sharma stated way back in 1966 in his concise paper "Epistemological Negative Dialectics of Indian Logic-Abhāva versus Anupalabdhi," (Dhirendra Sharma, "Epistemological Negative Dialectics of Indian Logic-Abhāva versus Anupalabdhi", Indo-Iranian Journal 9 (4), 1966: 291-300), the problem of negation is epistemological. Dhirendra Sharma says: "The problem of negation is primarily an epistemological one: How do we know the absence of a thing?" (Sharma 1966: 291).
} 
identification, by means of a negation of all that which is not asserted or identified. R. S. Bhatnagar would add that at any point of time when an assertion is made there would be "multiple strands of thought, information, theories and cognitive heritage waiting to be attended by critical enquiry" (Bhatnagar 2006: 85), and they need to be assessed and evaluated by a certain process of elimination and rejection to arrive at a particular assertion of knowledge claim. That is why R. S. Bhatnagar says that negation is to be accepted as an operative way in the cognitive activity. We assert in the cognition of " $x$ " as " $x$ " only by negating the possibility of cognizing " $x$ " as "p", "q" or " $r$ ". In this identification of cognitive process, the extinction of illusion concurs with the vanishing of the illusory object. R. S. Bhatnagar makes it comprehensively clear like this: "While a statement may be shown as false, or an argument may be found to be invalid, an action or a happening be assessed as wrong or unjust, the statement, argument, or the action or happening do not disappear. The negative characterization is not like erasing some undesirable or unwanted material. Even in the case of replacement or clearing, the material cleared or replaced remains, though in a modified form. On the contrary, in the case of illusory experience, termination of illusion coincides with the disappearance of the illusory object' (Bhatnagar 2006: 85). However, it is not the case with one when s/he cognizes one's own mistake or error. There is no total destruction of the consciousness or person in such activity. When one realizes one's mistake, there is a change in the attitude or consciousness. There is a "change of heart" or modification of one's attitude. Here "what is negated is not totally destroyed or rejected but which remains in a more complex whole as a component, though in a radically modified form" (Bhatnagar 2006: 86).

R. S. Bhatnagar was convinced of an epistemic rupture, while one adheres to negation. He writes: "Epistemic rupture between that-ness and what-ness involves another mode of non-being. Knowledge exhausts in terms of what-ness. But, as is well known, what-ness as distinguished from that-ness becomes unsubstantial. It seems to be deprived of the ground" (Bhatnagar 2006: 85). Bhatnagar takes recourse to Kant, but he finds Kant's explication still keeping the problem alive. Bhatnagar says: "The issue is well demonstrated by the culmination of empiricism in skepticism. While Kant tries to remedy the situation by bringing in the concept of 'given manifold,' yet his admission of thing-in-itself or noumenon resuscitates the problem. The question is: what is the matter in which qualities are supposed to inhere or what is the noumenon which backs phenomena? Epistemically the answer has often been proposed in negative terms" (Bhatnagar 2006: 85). An explanation on "what-ness" and "that-ness" that R. S. Bhatnagar speaks of could be given in a Buddhist phraseology. "That-ness" is "such-ness" or tathatā in Mahayana Buddhism. It does not speak of any qualities or attributes of being "this" or "that". Tathatā is śūnyatā which defies all characterization and denotation. No words can express tathata or what it is as it is. This is because there is an ineffability in that-ness. That is why it is said as nirvikalpa in the Mādhyamika system. The term nirvikalpa in Nāgārjuna ${ }^{3}$ would

\footnotetext{
3 In this regard, it is interesting to note what Siderits and Katsuara, with reference to nirvikalpa in Mülamadhyamaka-kārika 18 , 9, writes: "To say that reality lacks many separate meanings is to say that all things are fundamentally of the same nature-namely, empty of intrinsic nature. But the commentators all add that this is also a consequence of reality's being grasped without using falsifying conceptu-
} 
imply without any vikalpa. What is that is meant by nirvikalpa in Nāgārjuna? It is translated as "devoid of falsifying conceptualization" (Siderits and Katsura 2013: 202), "non-discriminative" (Inada 1993: 115), and "not thought" (Garfield 1995: 49). Vikalpa is conceptualization and its equivalent in the Mādhyamika thought is prapañca; and nirvikalpa would be nișprapañca. The rupture that Bhatnagar speaks of could be well fathomed, as mentioned above, when one understands the nuances of tathatā in Buddhist Mahayana thought. R. S. Bhatnagar thought that the epistemic rupture between that-ness and what-ness involves another mode of non-being. There is an epistemic rupture, Bhatnagar would argue, when one analyses the notion of "absence". How can one know that which is absent? The epistemic rupture Bhatnagar speaks of has always been there in the history of ontology, particularly when thinkers spoke of "absence". There can be a rupture between subject and object, the subject that cognizes and the object that is cognized. That is why it is said that in traditional epistemology we see a split between subject and object, and one "tries to ask how the subject can know the object" (Iyer 2014: 173). The dichotomy between subject and object within epistemology is directly related to representational, logical and causal-inferential forms of thinking, and it is inevitable (Iyer 2014: 173-174). The rupture that R. S. Bhatnagar has mind is more crucial than that which we mentioned here just now. In this case with "absence", there is an absolute "epistemic rupture", unlike the subject and object dichotomy mentioned above. It is interesting to note what a recent study on epistemic rupture says: "Rupture is not a moment that fades away but a recurrence within consciousness that is a testament to the incompleteness of epistemology. After all, if knowledge were wholly complete, if there was no space left in being, there would be no epistemological possibility of rupture. ... Yet rupture can never become the status quo. As it is coextensive to the dominant epistemologies, it is impossible to remain wholly within rupture. What remains after the break is not the rupture but a new epistemological system of being-which will, in time, be broken from as well" (Kingsmith 2017: 596-597). Therefore, the epistemic rupture has a nuanced underpinning. It is heartening to see that R.S. Bhatnagar brought out this epistemic rupture between "what-ness" and "that-ness".

\section{Negation and Ontology}

The second aspect that one finds in R. S. Bhatnagar is his take on ontological commitment. He would say, ontologically the notion of "absence" is nothing but "negation" or "non-being" where there is a non-availability of things, persons and documents. It has a positive aspect as an "absence" which will serve as "a spur in search and research in various situations" (Bhatnagar 2006: 86). According to R. $\mathrm{S}$. Bhatnagar this absence will lead to discoveries and inventions. When it comes

Footnote 3 (continued)

alization. For if nothing has an intrinsic nature, then a correct seeing of things cannot use the nature of things in order to draw conceptual distinctions. In order to discriminate between "this" and "that", one must be able to locate some difference in the nature of "this" and "that". This will prove impossible if things lack their own natures" (Siderits and Katsura 2013: 203). 
to art and artefacts, and the aesthetics therein, it was because of the "absence" that new creativity took place. R. S. Bhatnagar liberally speaks of the absence which is nothing but a negation that ushers in novel elements in creativity- "creative realm of action", where new creation takes place. He puts it in this way: "Creativity presupposes the absence or non-existence of something. This something may be some entity or some form of pattern. Bringing out something or creating a form which did not exist earlier reflects a transition from non-being" (Bhatnagar 2006: 86). There could be objection to it. R. S. Bhatnagar addresses this in this way: "Whatever is brought into existence as a creative artifact, already existed there in the realm of thought and imagination. Keeping this in view, one may say that it is wrong to think that creativity is a transition from non-being to being" (Bhatnagar 2006: 86). But whatever exists in "space-time" is different from that which exists in mental realms, for "the mental items cannot be treated or categorized in the same as physical items" (Bhatnagar 2006:86-87). Thus, art and aesthetic creations are novel items in the inventory of things that we encounter in the world of our existence which had no prior existence as physical things. But there could be a problem, even, in this sort of argument as well. One could call attention to the fact that the material used in any creative act already existed in physical modus. The creative act gives these existing materials some novel look, but ontologically they are not something new in toto. R. S. Bhatnagar explains that "even while it is accepted that the material and the tools with which the creator works exist, the form which exists in thought or imagination prior to actualization does not have the being that the finished product has. Actual usage of the term "being" may have more usages than one but it would create unnecessary problems to postulate as many ontologies" (Bhatnagar 2006: 87). Additionally, R. S. Bhatnagar would argue: "Modelling, remodeling, formation or transformation can be understood as an assemblage, combination of a given manifold in desirable composition. Such process would involve some displacement, reshuffling and even destruction. Thus, destination, that is, being involves some reduction to the non-being too" (Bhatnagar 2006: 87). Subsequently, there could be a question whether there is any sort of violence in creativity, as creativity, in some sense, implies destruction. R. S. Bhatnagar has thought about this aspect and he has this to say in this regard: "Creativity also implies destruction. To destroy is to be violent. But it would be odd to suppose that creativity implies violence. Violence is negation of personhood. It is basically asymmetric. Creative, on the contrary, may be said to be an enfoldment of what is personal in a world of sharing. Such a world would be constituted by symmetry of persons. Violence is the nihilation of the other. Thus, violence is a manifestation of extreme egoism. "I" derecognizes "you". Non-violence is based in the perception of the unity of being in every human being. But the unity has to be compatible with uniqueness" (Bhatnagar 2006: 87). R. S. Bhatnagar, thus, comprehends ontological problem found in creativity where there is an absence or negation and, at the same time, there is a seeming violence or destruction.

R. S. Bhatnagar's treatment of negation in relation to his ontological commitment that we have just discussed above has the corollary to his take on "being" and "nonbeing". R. S. Bhatnagar would say when it comes to philosophizing over "negation", it becomes clearer that "negation" is a necessity in our real world of life and thought. Bhatnagar argues that in order to comprehend and say something on the "being", 
one has to posit the notion of "non-being". He says: "In the Gita (2.16) it is said, 'non-being does not exist, being is not-being' and further in 2.17 'the indestructible pervades all that is there.' Parmenides is said to have written... 'being is, but nothing is not.' He also wrote, 'How could what is, perish?' How could it could have come to be? For it came into being, it is not; nor is it, if ever it is going to be.' Thus being alone is; it exhausts existence; it is indestructible and nothing else is. While this view insists on the reality of being, it also requires the addendum 'is not nonbeing"” (Bhatnagar 2006: 83). Explaining it further, R. S. Bhatnagar shows how the two degrees of reality propounded in both Parmenides (the way of truth and the way of opinion) and Advaita (paramārtha and vyavahāra) would say that "non-being forms an addendum in the doctrine of transcendental being, it is as much a necessity in the realm in which we live and die" (Bhatnagar 2006: 84). The take of R. S. Bhatnagar here is on the two truths paradigm in Indian philosophy; and its most representative account is found in Nāgārjuna, ${ }^{4}$ (though the Advaitic degrees of reality have been discussed much, its chronological existence is post-Nāgārjuna). The doctrine of two truths is, in no way, the brainchild of Nāgārjuna, as it can be seen in the early canonical texts of Buddhism. But he certainly gave it a pronounced expression in his writings particularly in his magnum opus, the Madhyamakaśāstram chapter 24: 1-40 (MK, Nāgārjuna 1960: 209-226). We have a large pool of philosophical literature available on two truths paradigm of Nāgārjuna (Murti 1998:243-255; Nayak 2001: 33-44, Siderits and Katsura 2013: 267-288, Garlfield 1995: 67-72 and 293-321). When R. S. Bhatnagar says that the "realm in which we live and die", what he implies is the world of here and now; and this world of here and now is very important as far as our philosophizing is concerned. One cannot ignore or negate it. In this sense Nāgārjuna's wise saying would enlighten us: there is not even the slightest difference between nirvāṇa and samsāra ${ }^{5}$; Na nirvānasya samsārāt kimcidasti viśeșanam (MK 25: 19). and without being in the vyavahära, one cannot reach paramärtha. ${ }^{6}$ The existence and operation of anything in terms of conventional and real are complementary. Hence, it could be said "negation, like affirmation, is in the first instance a relation of meaning and not a relation of being" (Heinemann 1943-1944: 147).

\footnotetext{
4 The doctrine of two truths in Nāgārjuna's scheme is of great importance for a flawless understanding of his thought. The real import of the doctrine of two truths in the Mādhyamika is a matter of dispute among the scholars. There is no disagreement among the scholars that Nāgārjuna has definitely stated about the two truths, namely loka-samirti satya (conventional truth) and paramārtha satya (real/ultimate truth). It also informs us that the entire teaching of the Buddha is based on the two truths (Madhyamaka Karika 24, 8). Nāgārjuna further made it clear that those who do not know the distinction between these two truths do not fathom the deep significations of the Buddha's teaching (MK 24, 9). All Mādhyamika treatises take the two truths as fundamental to the system. Jay Garfield speaks of two realities and two truths in this way: "conventional reality and ultimate reality. Correspondingly there are Two Truths: conventional truth, the truth about conventional reality; and ultimate truth, the truth about the ultimate reality-qua ultimate reality" (Garfield 2002: 90).

5 Na samsārasya nirvāṇāt kimcadasti viśeșaṇam;:

6 VyavahĀramanāśritya paramārtho na deśyate (MK 24: 10).
} 


\section{Negation and Dialectics}

The third interesting point that R. S. Bhatnagar deals with in "negation" is dialectics. R. S. Bhatnagar says: "Dialectical movement in thought and process of growth in living beings exhibit such a phenomenon. Thus, negativity operates in rejection, destruction as well as assimilation" (Bhatnagar 2006: 86). If we take all the three points (two points discussed above, namely epistemology and ontology in relation to negation, and this being the third, namely dialectics) under the splendour of negation, we could mark the entire negation as a dialectical process. Dialectic is that process of opposites which assigns to philosophy an intermediate position in reality. "Dialectics describes both existence and thinking in terms of opposites. At the same time, it does not take the opposites as its primary datum, but regards them as the aspects and outcome of a process" (Lee 1947: 5). Opposites are the outcome of a process of opposing by way of affirmation and negation. "This process, by which opposites are generated-and also, it will presently appear, united-dialectic calls negation. Thus, negation is a central concept in dialectic, for it describes something which is even more ultimate than the opposites themselves" (Lee 1947: 5). Here, let us also remind ourselves that "dialectics" for the Greek thinkers like Plato was to show something positive. In Plato, dialectics intended to establish something positive through the thought-means of the negation; the figure of a negation of the negation named this precisely. However, Theodor W. Adorno, in his Negative Dialectics opposed the traditional views that we find in Plato, and he claimed "to emancipate dialectics from these types of affirmative essence, without relinquishing anything in terms of determinacy" (Adorno 2004: xix). ${ }^{7}$ In this connection, it must be mentioned here that in dialectics there are real negation, transformative negation, radical negation of determinate, indeterminate, fuzzy, duplicitous and a mélange (Bhaskar 2008: 4-7). In the discussion on dialectics, one finds the ingenuity of R. $\mathrm{S}$. Bhatnagar when he thinks aloud on the positive and creative unfoldment of freedom and uniqueness that is implied in negation, which in that sense, "splendoured". The splendour of negation is, thus, for perfection. This is something that attracts any ingenious thinker. He writes: "The positive and creative unfoldment of freedom and uniqueness also leads the individual to negate the given state of affairs which is never as perfect and ideal as to leave no room for initiative or effort. The idea of perfection and ideality, over times and cultures, has manifested itself from desirelessness to desire to fullness comprehending maximum variety. In one case, the negative

\footnotetext{
7 According to Adorno, dialectics is not a standpoint. He writes: "No theory today escapes the marketplace. Each one is offered as a possibility among competing opinions; all are put up for choice; all are swallowed. There are no blinders for thought to don against this, and the self-righteous conviction that my own theory is spared that fate will surely deteriorate into self-advertising. But neither need dialectics be muted by such rebuke, or by the concomitant charge of its superfluity, of being a method slapped on outwardly, at random. The name of dialectics says no more, to begin with, than that objects do not go into their concepts without leaving a remainder, that they come to contradict the traditional norm of adequacy. Contradiction is not what Hegel's absolute idealism was bound to transfigure it into: it is not of the essence in a Heraclitean sense. It indicates the untruth of identity, the fact that the concept does not exhaust the thing conceived. ... Dialectics is the consistent sense of nonidentity. It does not begin by taking a standpoint" (Adorno 2004: 4-5).
} 
leads to the denial of all that is there or could be, for it can never be free of contingency in terms of values, and in the other case, to a ceaseless effort and venture to attain fulfilment. In both the cases, it is 'what is not' which moves the lever" (Bhatnagar 2006: 90). If the dialectics facet is explored further, as R. S. Bhatnagar would do, into other field of study, it is a verity that psychologists and social scientists have shown through their research the benefits from negation, and "negative emotions" like sadness help one to pay more minute attention to external details which provide a wide range of benefits in information processing and social behaviour (Forgas et al. 2006: 3-18); and it makes accuracy in memory of events in life (Forgas 2006: 269-290). Why there is a negation? Because the given state (or state of affairs) is not perfect. This is not the ideal that one aspires for. However, though one negates the given state of affairs as imperfect and non-ideal, the ideal can never be captured or embraced, even if one uses the tool of negation. The ideal will remain the ideal. The moment the ideal is captured, it ceases to be an ideal. Hence, even negation has its limitations in its dialectics, yet "negation is indispensable for a finite mind" (Heinemann 1943-1944: 152).

\section{The Splendour of Negation with a Buddhist Tinge}

R. S. Bhatnagar's engagement with negation is not complete unless one takes into consideration "negation" as an integral part of philosophizing in India, whether it is the Buddhist tradition or the any other tradition. One encounters the philosophical "exercise" (Bhatnagar 2006: 83) on negation enormously in Buddhist thought. It does not mean other traditions in Indian philosophy have not dealt with it. One of the most fascinating views on negation is how the Mīmāmsaka thinker Kumārila considers negation (Tripathi 1977: 345-346, Bilimoria 2016: 183-02). ${ }^{8}$ The Naiyāyikas

\footnotetext{
${ }^{8}$ One of most fascinating views on negation is how the Mīmāmsaka thinker Kumārila considers negation. Chhote Lal Tripathi writes: "According realists of the Pūrva Mīmāmsā school of Kumārila negation is as real as any other object of the world. It is not like a mirage or the objects of dream. It is real like a cow or a horse. According to them there is no difference between a present object and an absent object so far as its reality is concerned. Objects are two kinds-positive and negative. The former are characterized by existence and the latter by non-existence. Further, every object has two aspects, the existent and non-existent. The existent aspect is cognized through perception with the help of five sense organs, and the non-existent aspect is cognized by a mode of cognition which is called negation of non-apprehension. According to Śabara negation implies the absence of the means of cognition of positive objects and gives rise to the notion of a certain unseen and non-existent object. Explaining Śabara, Kumārila says that negation as a means of cognition consist in the non-functioning of perception and other means of cognition and apprehends the objects which is beyond the comprehension of the five means of cognition" (Tripathi 1977: 345-346). P. Bilimoria in one of his recent studies shows how the uniquely Mīmāmsā position - as distinct from the Nyāya's - is that everything is counter-negatively marked by its own prior and future non-existence. That is, when something, $\mathrm{x}$, that was there, is cognized as being "absent", this really is a perception of its "non-existent" other, and "non-existence" is arguably a real universal. Bilimoria would state that this view of the Mīmāmsakās makes way for a Meinongian (Alexius Meinong Ritter von Handschuchsheim who became primarily renowned for the theory of objects-Gegenstandstheorie, 1904 - a kind of a priori ontological account that introduces and considers systematically not only existent but also non-existent objects) knowing of non-existent objects (Bilimoria 2016: 183-202).
} 
too consider negation as real (Matilal 1968: 87-89). ${ }^{9}$ Advaita Vedānta is also known for its negation in via negativa in order to establish the nirviśeșa Brahman with the method of negation found in neti neti ${ }^{10}$ (Malkani 1966: 82-83, Pande 1994: 200 234).

When it comes to the Buddhist thought, in its entire career replete with schools and sub-schools, negation is central to it. ${ }^{11}$ In the Buddhist thought, there is an obvious intent of the inadequacy of language implied in the negative way or via negativa (not the theological via negativa). The fourteen unanswered questions and even the silence of the Buddha before his first preaching indirectly indicated the negation. (However, that silence of the Buddha could be subjected to different interpretations.) And the negative way in the Buddhist thought, in that sense, started right from the Buddha and it has had a long trajectory. The "inexpressible" (avyākata in Pāli or avyākrta-vastūni in Sanskrit) occurs in many dialogues of the Buddha himself. ${ }^{12}$

\footnotetext{
9 The Naiyāyikas also holds negation as real, and negation has an objective reality like substance, attribute, universal, particular, action and inherence. The negative facts are real as positive facts (Matilal 1968: 87-89).
}

10 G. R. Malkani explains it so lucidly in this way: "The negative statement is always a correcting statement-it corrects the original error. 'I am this.' We are prone to identify the 'I,' the pure self, with all kinds of objects, both external and internal. This is the fundamental error in Advaita Vedānta. What is not object of any kind, and what is in reality self-effulgent and transcendent in character is taken to be an object of some kind and therefore, finite, limited, and non-intelligent. We need to negate all such objects, which constitute an ascending and graded series from gross to the subtle. This is the method of negation, neti, neti, 'not this, not this.' When this negation is carried to the logical and ontological limits, what is left is the ultimate subject (Ātman), which is one with Brahman. ... The fundamental Vedāntic thesis is quite explicit on this very subject. Brahman is real (Brahma-satyam), the world is illusory (jaganmithyā), and there is no difference between the individual self and the universal Self (jīvo brahmaiva na'parah)" (Malkani, 1966: 82-83). G. C. Pande' s explanation makes it still clearer. He writes: "[W]hen applied to Brahman the term knowledge does not have the usual sense of activity or agent. Hence the application of the term which denotes a property of intelligence to Brahman can only be metaphorical. 'Jñāna-śabdena tallaksyate' (For knowledge [of Brahman] by words is that which is indicated, not stated). The same is true of the word satya which commonly denotes the universal common to external objects and can hardly be applied to Brahman which lacks all particular determinations. Hence the term satya, etc., being used together limit each other and indicate Brahman by demarcating it from their usual references. Thus Brahman is indicated by words even while it remains unspoken, beyond speech and thought (Pande 1994: 200). Further, "even if verbal knowledge may sometimes ne immediate, can words give knowledge of the Self of Brahman? Is not language defined to empirical objects, finite and rational? Sankara's answer is that while language cannot describe or define Brahman, it can indicate it obliquely by a process of negation Thus terms like 'being' or 'knowledge' may indicate Brahman when they are freed from all limiting determinations. Brahman is to be reached through the negation of all determination, i.e. as what is properly finite" (Pande 1994: 234).

11 There is an exposition on the significance of negation in Buddhism in Genjun Sasaki's Linguistic Approach to Buddhist Thought (Sasaki 1992: 1-75).

${ }^{12}$ The Cüla-Mälunkyasutta of Majjhima Nikāya is the classical example to it (Majhima Nikāya (2004) I, 426-432: Vol. II, 97-101). "Wherefore, Mālunkyaputta, understand as not explained what has not been explained by me" (Majjhima Nikāya I, 432: Vol. II, 101). Again, the Aggi-Vacchagottasutta is another example (Majjhima Nikāya I, 484-489: Vol. II, 162-167). In his Abhidharmakośa-bhāṣya, Vasubandhu explains the "inexpressible" as questions that does not deserve an answer, and thus, such an answer should be declined. He says: "The Sūtra calls indeterminate (avyākrta) the questions to which an answer should not be given (sthāpanìyapraśna), that is to say, this question is known as "not answered" (avyākrta); it is not explained (kathita) because it should be declined. The object of such a question is called an indeterminate point (avyākrta-vastu)" (AKB (2012) V, 21, 1691). 
This "inexpressible" need not be in the sense of mystical "ineffability". B. K. Matilal says in this regard: "Whether the Buddha himself supported the ineffability doctrine of not, is not known. Evidence is not available to prove the point. But is true that the Buddha was responsible for mobilizing what may be called a thoroughgoing 'de-personalization' of the philosophic language or discourse. Thus, he rejected terms like, 'soul', 'self', 'person', or 'living being' (ätman, pudgala, jīva, or sattva) as not meaning anything" (Matilal 1975: 231).

The negation is inherent in the Buddhist thought right from the beginning, and it could be seen in all the schools of Buddhism. A. K. Chatterjee has rightly pointed out that "negativism is inherent in the structure of Buddhist thought. Negativism beginning with the doctrine of avyakrta (inexpressible), through the doctrine of śūnyatā, adopted by both Mādhyamika and Yogācāra, finally culminates in the theory of language in Dinnāga School" (Chatterjee 2007: 13). By "negativism" A. K. Chatterjee does not imply negativity in the sense of "life-negating" or negativity in emotional and psychological attitude. By "negativism" his import is the use of "negation", in language and semantics, as we in this sentence: "Every determination of meaning is either affirmative or negative" (Heinemann 1943-1944: 151). I also would like to make it clear here that A. K. Chatterjee's expression of "negativism" does not imply to the misunderstood charge of "negativism" by the nonBuddhist thinkers of the past. ${ }^{13}$ The Buddhist paradigm of negation with all the "metaphors of negativity" has a different connotation. It must be also mentioned here that the implication of "negation" is not a blatant negation per se, but it has a connotation of "absence" as in anattā (Sugunasiri 2011: 101-134). The negative way is an employment of language in the Buddhist thought which unravels the riddle of language in its semantics, and expresses the asymmetry between language and reality. It is because according to Buddhist interpretation "what is signified by a word is neither a subjective idea nor an objective reality, but something fictitious and unreal". ${ }^{14}$ We find that the negation is inherent in Buddhist thought whether it is the avyākrta (inexpressible), śūnyatā (emptiness) or apoha (exclusion). ${ }^{15}$ Here

\footnotetext{
13 My reference here is to the charge of "negativism" that non-Buddhist thinkers attributed to Buddhist theory of meaning which was a misunderstood version, if I am allowed to say so. Non-Buddhist critics like Uddyotkara, Kumārila, Bhāmaha, and Udayana saw the Buddhist approach as a theory of negative. Taking recourse to them K. Kunjunni Raja had stated that the Buddhist theory is "a negative approach towards meaning" (Raja 1954: 188). The charge of "negativism" used to get rebutted by Buddhist logicians like Dharmakīrti (Dharmakīrti 1943: 248-263) and Jñānaśrīmitra (Jñānaśrīmitra 1959: 201-232). See also Dhirendra Sharma's study on apoha (Sharma 1969: 19-45).

14 Satkari Mookerjee explains this: "The fact of the matter is that both the speaker and the hearer apprehend in fact and reality a mental image, a subjective content and not any objective fact; but the speaker thinks that he presents an objective fact to the hearer and the hearer too is deluded into thinking that the presented meaning is not a mental image, but an objective verity. The speaker and the hearer are both laboring under a common delusion" (Mookerjee 2006: 116).

15 It could be further clarified with the explanation of negative constituent, while dealing with "exclusion" (apoha) in one of the recent studies that takes recourse to the late Indian Buddhist philosopher Jñ̄naśrïmitra (972-1025 AD). It goes like this: “...the content of our verbal (and also inferential and conceptual) awareness must be taken to be a complex object consisting of both a positive and a negative element. In accordance with our everyday linguistic experiences, a positive object must be taken to be what is primarily expressed by language. But an additional negative element, exclusion, must be taken to be a qualifier of that positive object. While we can act only towards positive entities, it is only through
} 
"negation" is a "cognitive-linguistic phenomenon. Negation does not pertain to what $i s$, it is involved in what we think about that which is" (Yadav 1977: 459). Thus, negation is directed towards what is being perceived, for all that one encounters in the conventional (samvr $t i)$ is conceptually and linguistically fixed (drsțti).

The splendour of negation gets more illumined in the Mahāyāna tradition where it gets more rigour and prominence. The Mādhyamika thought with its notion of śūnyatā harbours much on negation. The Buddhist logical school (with Dignāga ${ }^{16}$ fifth/sixth century $\mathrm{AD}$ — and his renowned commentator Dharmakīrti ${ }^{17}$ — seventh century AD), with its theory of apoha (Sharma 1968: 4-10), furthers and sharpens the negative paradigm with its theory of double negation. ${ }^{18}$ In the hands of the later Buddhist thinkers like Śāntarakșita ${ }^{19}$ (eighth century AD) and Ratnakīrti ${ }^{20}$ (tenth century AD) the negation gets a newer twist. Sanntarakșita establishes the negative way, with reference to apoha, on two levels, namely relative and absolute negations. The relative negation (paryudāsa), still has two kinds of negation-negation of the ideal universal or conceptual (buddhyātman) and negation of object (arthātman). A recent study states: "He (Śāntarakṣita) establishes that apoha is of two kinds due to the difference between relative and absolute negation. Again, the relative negation is also of two kinds due to the difference of conception of idea and object.... Absolute negation (prasajya pratiședha) is complete denial or prohibition. In the relative negation, the negative suffix which bears this meaning (as in anātman, the negative suffix ana) posits two facts-that there is a negation of some positive/present entity and simultaneously it also states that instead of that entity which has been negated

\section{Footnote 15 (continued)}

exclusion that we can pick out the appropriate objects for that activity by distinguishing them from those that are inappropriate" (McCrea and Patil 2010: 28).

16 Dignāga's Pramānasamuccaya deals with apoha, especially its second chapter titled Svārthānumāna and the fifth chapter titled Apoha. J. L. Shaw explains Dignāga's notion of apoha in this way: "According to Dignāga, as quoted by Mallavādī, a word expresses its meaning by excluding the meaning of all other words from its own meaning. This remark suggests that in order to express the meanings of all other words are to be excluded. For example, the word 'cow' expresses its meaning by excluding the meaning of 'non-cow,' i.e. the meanings of words like 'horse,' 'dog,' etc. This view might suggest that the exclusion of the meanings of their words is not the meaning of a word. It has also been said that according to Dignāga a word is caused by or has its origin in an imaginative construction or concept (vikalpa), and an imaginative construction (vikalpa) is caused by or has its origin in a word. This remark suggests that both a word and an imaginative construction have the same nature, i.e. both of them are in the realm of unreality. Since the imaginative constructions or the concepts are unreal, the words which are caused by them are also unreal. If the words are taken as unique particulars, then there can be no relation between a word-particular and object-particular, because both of them are equally unique particulars (svalakșanas). Hence, the meaning-relation (vācya-vācaka sambandha) holds between a word-universal (i.e. a wordimaginative-construction) and object-universal (i.e. an object-imaginative-construction) (Shaw 1978: 65).

17 Dharmakïrti wrote a commentary on Pramānasamuccaya of Dignāga after the name Pramāṇavārttikakārikā, or simply Pramānavārttika. Dharmakirti's Pramānavārttika deals with apoha, especially the first chapter Pramānasiddhih, the second chapter Pratyakșam; and the third chapter Svārthānumānam:

18 One could get the latest discussions and debates on apoha by the contemporary Buddhist scholars in the book Buddhist Nominalism and Human Cognition (Siderits, Tillemans, and Chakrabarti, 2011).

19 Śñntarakșita's Tattvasamigraha, verses 867-1212 deal with apoha and the negative way implied therein (Śāntaraksita 2006).

${ }^{20}$ Ratnakïrti's Apohasiddhi, the complete work, deals with apoha and negative way (Ratnakïrti 1957). 
something is present. Consider the very technical term in Buddhist philosophyanatman. It denies the existence of ätman on one hand and on the other it posits the existence of dharma.... Santarakșita defines now what is the absolute negation. In the statement like 'cow' is not non-cow, there is absolute/complete negation of 'noncow" (Mishra 2008: 115-117). Relative negation is known directly, but absolute negation is known only through implication. ${ }^{21}$

Ratnakīrti gave a new orientation to "negation" in the Buddhist thought by interpreting apoha as "positive qualified by negation", (Mishra 2008: 136) in the sense, apoha is not merely an exclusion of non-X, "but the meaning of a term is the positive thing qualified by the exclusion of the other" (Mishra 2008: 121). Dhirendra Sharma appraises Ratnakīrti's view and says: "(T)heory of apoha corresponds primarily to negation by implication and involves simple negation. According Ratnakīrt, negation by implication (paryudāsa) is found rooted (niyata) in the immediate knowledge of the thing and thus is commonly applied to both affirmative and (simple) negative propositions. This means that, logically speaking, there can be neither a pure affirmation nor a pure negation. This is the reason why one does not go and tie a horse or a dog when asked to tie a cow. Apoha is the basis of discriminator behaviour in everyday life, and differentiation is the prime factor of all reflective thinking" (Sharma 1968: 10).

The negation in Buddhism has the import of "inexpressible", ${ }^{22}$ whether it is with regard to properties of things or any entity per se. Thus, negation is central to Buddhist thought ${ }^{23}$ that has always upheld the interdependence and mutuality

\footnotetext{
${ }^{21}$ It is explained so clearly in a recent study: Śāntarakșita and Kamalaśîla subsequently elaborate more and more upon the notion of exclusion, apoha, noting the existence of two types negation: relative negation or exclusion properly, paryudāsa, and absolute negation or denial, niședha. Relative negation is itself divided into two types: due to a conceptual deference (buddhyātma), and due to an objective difference (arthātma). Things are in and of themselves reciprocally different one with respect to the other, but due to a limited power (niyataśakti) some of them develop some sort of conception of similarity. On the basis of such a conception, a kind of reflection (pratibimbaka) arises. This reflection is erroneously conceived as an "object". Apoha is only the conception of such a reflection. The denotative function of the word is only the production of such a reflection, the exclusion of other objects from its own semantic sphere. Relative negation is known directly, whereas absolute negation is known through implication" (Pelissero 2014: 28).

22 Explaining it with recourse to Jñ̄anaśrīmitra, the later Indian Buddhist philosopher, McCrea and Patil explains: "If the question is 'What is it that is expressed by words?' then, having set out these options (1) on the basis of appearance, (2) on the basis of determination, or (3) really, the answers are, in order, (1) 'the image that is excluded from what is other, that resides in conceptual awareness'; (2) 'the particular that is excluded from what is other'; or (3) 'nothing.' This has already been said. Therefore, establishing the position that words and inferential reasons have exclusions as their objects is for the sake of making it known that all properties are inexpressible" (McCrea and Patil 2010: 96-97).

23 The problem empty terms-expressions which are meaningful, but not referring to anything real could be found in galore in Buddhist thought. Z. Yao writes in this regard: "Many basic doctrines of Buddhist philosophy can be stated as negative existential propositions. For instance, 'no-self' (anātman) means 'self does not exist'; impermanence (anitya) means 'permanent entities do not exist'; 'emptiness' (śünyatā) means 'intrinsic nature does not exist'(niḩsvabhāvatā). The subject of these propositions all considered empty terms because as stated in the propositions themselves, they do not really exist. Therefore, Buddhist tradition has had to face the problem of empty subject terms from its very inception". Even though the problem of empty subject was embedded in in the tradition itself, it was not treated in any systematic way until the development of Buddhist logic in the sixth century" (Yao 2009: 384).
} 
of relations (pratityasamutpāda), for negation is "one of the most primitive constructive relations which are presupposed by any order of meaning" (Heinemann 1943-1944: 151). Negation keeps the dialectical approach in Buddhism thriving, as "affirmation" and "negation", "existence" and "non-existence", "svabhāva" and "parabhāva", "being" and "non-being", " $S$ " and "not- $S$ " are mutually constructed. Had R. S. Bhatnagar brought Buddhist facet and paradigm of negation to his exercise and scheme of thought on negation, the essay would have a different take and outlook altogether. However, that restraint does not, in any way, subtract the merit of this thought provoking treatise of R. S. Bhatnagar. One finds the philosophical reflection on the splendour of negation that R. S. Bhatnagar makes exceedingly rewarding and intellectually stimulating.

\section{Bhatnagar on Negation and Death}

In conclusion, let me indulge myself a bit with what was R. S. Bhatnagar's cogitation on death, if "death" is taken as "the negative in its dreaded form" (Bhatnagar 2006: 90). The last musing on negation that R. S. Bhatnagar made in his succinct essay was on death. He was convinced, even if "the negative in its dreaded form as death and impossibility" (Bhatnagar 2006: 90), has its splendourous influence and force on life. The reality of death could bring "gloom and despair in life" (Bhatnagar 2006: 90), but the verity of death brings meaning to life. Life has meaning, worth, or value, as it must come to an end. Karl Popper has said: "There are those who think that life is valueless, because it comes to an end. They fail to see that the opposite argument might also be proposed: that if there were no end of life, life would have no value; that it is, in part, the ever-present danger of losing it which helps to bring home to us the value of life" (Popper 1977: 148). In spite of a weird possibility of "gloom and despair" in some, the reality of death has led "to courage and source force" (Bhatnagar 2006: 90) for many. One is able to go forward with courage and faith in mind, as Socrates had bravely faced death. During his defence, Socrates proposed to convince the jury that he was not afraid of death by giving them his proof of deed, not word. On the final day of his life, Socrates made lengthy and complex attempt to convince his friends that death is nothing to be afraid of (Plato's Phaedo 1951: \#100-118 pp. 53-74). The courage to face death comes from the mind, the courage cultivated by the mind and moral values. This courage takes time, and it is the ability to perform with a cool head the heroic acts we normally carry out. And the same courage will make one face death. That is why Bhatnagar said: "To live well is perhaps to learn to die well" (Bhatnagar 2006: 90) or as it is in Latin ars vivendi est ars moriendi (art of living is the art of dying or living well is dying well). ${ }^{24}$

\footnotetext{
${ }^{24}$ Ars Moriendi (The Art of Dying) are two related texts written in Latin c. 1415-1450 AD explaining how to die well. It was very popular text in the fifteenth century which was translated into almost all the European languages. Its popularity declined when the treatise called De Praeparatione ad Mortem of Erasmus (Desiderius Erasmus Roterodamus) appeared in 1533.
} 
It means that ars moriendi (art of dying/dying well) cannot be isolated from ars vivendi (art of living/living well).

Let me reflect a little more on R. S. Bhatnagar's final statement "to live well is perhaps to learn die well" (Bhatnagar 2006: 90). The pandemic of Covid-19 at the present time claims lives of global population and thrusts death to the forepart of human consciousness. One has to accept and acknowledge the human finitude, and death is a real inevitability that one has to encounter personally. Seeing the deaths due to Covid-19, one can describe it in epistemological and existential senses (Bishop 2015: 19-32). One wonders whether philosophers are less interested in death than the fear of death. ${ }^{25}$ R. S. Bhatnagar does not say anything about the fear of death, but the reality of death, and the learning to embrace that death well. To this R. S. Bhatnagar affirms that living well is, conceivably, the learning to die well. It is ars bene vivendi est ars bene moriendi- "the art of living well is the art of dying well". The art of dying well has to be part of the moral equipment of a good life, a life that is being lived well. R. S. Bhatnagar's view on death was in line with the view of Alasdair MacIntyre who suggested a revival of moral realism-a realist approach to virtue - will be able to speak of "dying well". MacIntyre, opined that unless and until we hold on to moral realism, there is "no good death" possibledying well is impossible - because there is no reasoned social structures, rituals, traditions and institutions that can give dying meaning. It is because, MacIntyre would say, we continue to glorify the individual and trivialize death (Macintyre 1978: 75-84), as we often say at the demise of someone, "it is a loss" and "we will miss her/him" and so on. An approach to moral realism will not have any problem in the view of dying well-that it is possible still to live well, and die well. Here, for R. S. Bhatnagar, death will never be "a great curse" (Nagel 1986: 224), as it is for Thomas Nagel. ${ }^{26}$

R. S. Bhatnagar's view goes well resonant with the Buddhist approach to death: live well to die well. Buddhism is a predominant voice in the philosophy of "good death" in terms of conscious dying. The Tibetan Book of the Dead or the Bardo Thodol is the best text available to us that teaches a good living for a good death. The good living is a constant awareness, that a person has, of the impermanence of things in life, the true nature of things, insight about life and death and an ethical life based on empathy and compassion (Rinpoche 2008: 15-105, 191-212). Knowing

\footnotetext{
25 Hayden Ramsay writes in this regard: "A brief glace at the literature death suggests philosophers are less interested in death than the fear of death. The fear of death was certainly the central issue for Epicurus and the Roman moral philosophers who reflected on his legacy. Later. Christians seemed not to philosophize about this fear itself so much as to accept it and try to offer rationales or remedies for it. Contemporary moral philosophy has returned to ancient Roman debates, making its central concern about death the rationality and/or inevitability of our fear" (Ramsay 2005: 418).

${ }^{26}$ For Thomas Nagel, death is "a great curse": "Some people believe in an afterlife. I do not; what I say will be based on the assumption that death is nothing, and final. I believe there is little to be said for it: it is a great curse, and I we truly face it nothing can make it palatable except the knowledge that by dying we can prevent an even greater evil. Otherwise, given the simple choice between living for another week and dying in five minutes I would always choose to live for another week; and by version of mathematical induction I conclude that I would be glad to live forever" (Nagel 1986: 224).
} 
the inevitability of death in one's life, one's well-lived life prepares one to die well. This is what Dalai Lama says about good life for a good death:

Death is a natural part of life, which we will surely have to face sooner or later. ... As a Buddhist, I view death as a normal process, a reality that I accept will occur as long as I remain in this earthly existence. Knowing that I cannot escape it, I see no point in worrying about it. ... Hoping for a peaceful death, we must cultivate peace in our mind, and in our way of life. ... from the Buddhist point of view, the actual experience of death is very important. So at the moment of death, in spite of the great variety of karmas we have accumulated, if we make special effort to generate virtuous state of mind, we may strengthen and activate a virtuous karma, and so bring about a happy rebirth. The actual point of death is also when the most profound and beneficial inner experience can come about. Through repeated acquaintance with the processes of death in meditation, an accomplished meditator can use his or her actual death to gain great spiritual realization. This is why experienced practitioners engage in meditative practices as they pass away. ... No less significant than preparing for our own death is helping others to die well. ...we should relieve them of the discomfort and anxiety, and assist them, as far as we can, to die with composure (Dalai Lama 2008: ix-x).

Thus, as Dalai Lama says, living a good life, cultivating peace in one's mind and in way of life, one hopes for a peaceful death. The realization of a Buddhist that the actual point of death is the moment when the most profound and beneficial inner experience can come about, makes a Buddhist aware of her/his empathetic responsibility to help others to die well. Hence, looking at R. S. Bhatnagar's final statement "to live well is perhaps to learn die well" (Bhatnagar 2006: 90), makes one fathom the profundity of thought that is implied in his well-chosen words of this dignified expression.

As W. B. Yeats cautioned us, while we would read and engage with his ideas, to "tread softly because you tread on my dreams" (Yeats 1903:60), ${ }^{27}$ so we should also make our philosophical pilgrimage, with utmost care and thoughtfulness, to the insightful cogitations of R. S. Bhatnagar of happy memory.

Acknowledgments The author would like to thank the two unknown reviewers. One of the reviewers had recommended the paper as it was in the first draft. The present version is the revised and modified one in the light of the comments and observations made by the other reviewer in her/his recommendation for a minor revision.

\section{References}

Adorno, T. W. (2004). Negative dialectics. London and New York: Routledge.

AKB: Vasubandhu. (2012). Abhidharmakośa-bhāșya, Vol. 1-4, L. de La Valle Poussin, G. L. Sagpo (tr), Delhi: Motilal Banarsidass Publishers.

Bhaskar, R. (2008). Dialectic: The pulse of freedom. London and New York: Routledge.

\footnotetext{
27 In the concluding lines of his shortest and most popular poem Aedh Wishes for the Cloths of Heaven, W. B. Yeats made us cogitate over: "But I, being poor, have only my dream; And I have spread my dreams under your feet; Tread softly because you tread on my dreams" (Yeats 1903: 60).
} 
Bhatnagar, R. S. (2006). Many splendoured negation. Journal of Indian Council of Philosophical Research, XXII(3), 83-90.

Bilimoria, P. (2016). Negation (abhāva), non-existents, and a distinctive pramāṇa in the NyāyaMīmāṃsā. In P. Bilimoria \& M. Hemmingsen (Eds.), Comparative philosophy and J.L. Shaw (Vol. 13, pp. 183-202)., Sophia studies in cross-cultural philosophy of traditions and cultures Cham: Springer.

Bishop, J. (2015). Finitude. In L. S. Dugdale (Ed.), Dying the twenty-first century: Toward a new ethical framework for the art of dying well (pp. 19-32). Cambridge: The MIT Press.

Chatterjee, A. K. (2007). Apoha: Buddhist theory of meaning. Journal of Indian Council of Philosophical Research, 24(2), 13-20.

Dahlstrom, D. (2010). Negation and being. The Review of Metaphysics, 64(2010), 247-271.

Dalai L., (2008). The "Foreword". In: P. Gaffney, A. Harvey (Eds), Rinpoche, Sogyal, The Tibetan book of living and dying, (pp. ix-x). London: Rider, an imprint of Ebury Publishing of Random House Group Company.

Dharmakīrti. (1943). Pramānavārrttika of Dharmakīrti, the first chapter with auto commentary svavr țti, and sub-commentary of Karṇakagomin svavr tti-țīka, R. Sānkrityāyana (ed). Allahabad: Kitab Mahal.

Downing, L. H. (2000). Negation, text worlds, and discourse: The Pragmatics of fiction. Stamford: Ablex Publishing Corporation.

Forgas, J. P. (2006). Affective influences on interpersonal behavior: Towards understanding the role of affect in everyday interactions. In J. P. Forgas (Ed.), Affect in social thinking and behaviour (pp. 269-290). New York: Psychology Press.

Forgas, J. P., Wyland, C. L., \& Laham, S. M. (2006). Hearts and minds: An introduction to the role of affect in social cognition and behaviour. In J. P. Forgas (Ed.), Affect in social thinking and behaviour (pp. 3-18). New York: Psychology Press.

Garfield, J. L. (1995). The fundamental wisdom of middle way: Nāgārjuna's Mūlamadhyamakakārikā. Oxford and New York: Oxford University Press.

Garfield, J. L. (2002). Empty words: Buddhist philosophy and cross-cultural interpretation. Oxford: Oxford University Press.

Heinemann, F. H. (1943-1944). "The meaning of negation”. In: Proceedings of the Aristotelian society new series 44 (1943-1944): 127-152.

Inada, K. (1993). Nāgārjuna: A translation of his Mūlamadhyamakakārikā with an introductory essay. Delhi: Sri Satguru Publications.

Iyer, A. (2014). Towards an epistemology of ruptures: The case of Heidegger and Foucault. London: Bloomsbury.

Jñānaśrīmitra (1959). Jñānaśrīmitra-nibandhāvalī (Twelves Buddhist philosophical works of Jñānaśrīmitra). In: A. Thakur (ed), Tibetan Sanskrit works series 5. Patna: Kashi Prasad Jayaswal Research Institute.

Kingsmith, A. T. (2017). On rupture: an intervention into epistemological disruptions of Machiavelli, Hobbes, and Hume. The Journal of Speculative Philosophy, 31(4), 596-597.

Lee, O. (1947). Dialectic and negation. Review of Metaphysics, 1(1), 3-23.

MacIntyre, A. (1978). The right to die garrulously. In E. McMullin (Ed.), Death and decision (pp. 75-84). Boulder: Westview Press.

Majjhima Nikāya (The middle length sayings) (2004). Vol. 1-3, I. B. Horner (ed), Delhi: Motilal Banarsidass Publishers.

Malkani, G. R. (1966). A discussion of Daya Krishna's views on advaitic Adhyāsa. Philosophy East and West, 16(1-2), 81-83.

Matilal, B. K. (1968). The Navya-Nyāya doctrine of negation: The semantics and ontology of negative statements in Navya-Nyāya philosophy. In D. H. H. Ingalls (Ed.), Harvard oriental studies (Vol. 46). Cambridge: Harvard University Press.

Matilal, B. (1975). Mysticism and reality: Ineffability. Journal of Indian Philosophy, 3(3-4), 217-252.

McCrea, L. J., \& Patil, P. G. (2010). Buddhist philosophy of language in India: Jñānaśrīmitra on exclusion. New York: Columbia University Press.

Mishra, R. K. (2008). Buddhist theory of meaning and literary analysis. D. K. Printworld: New Delhi.

Mookerjee, S. (2006). The Buddhist philosophy of universal flux, reprint. Delhi: Motilal Banarsidass Publishers.

Murti, T. R. V. (1998). The central philosophy of Buddhism: A study of the Mädhyamika system. New Delhi: HarperCollins. 
MK: Nāgārjuna, (1960). Madhyamakaśāstra of Nāgārjuna with the commentary Prasannapadā by Candrakīrti. Buddhist Sanskrit Texts No.10. ed. P. L. Vaidya. Darbhanga: The Mithila Institute of Post-graduate Studies and Research in Sanskrit Learning.

Nagel, T. (1986). The view from nowhere. New York and Oxford: Oxford University Press.

Nayak, G. C. (2001). Madhyamaka Śūnyatā: A reappraisal. New Delhi: Indian Council of Philosophical Research.

Pande, G. C. (1994). Life and thought of Śankarācārya. Delhi: Motilal Banarsidass Publishers.

Pelissero, A. (2014). Much Ado about nothing: Unsystematic notes on śūnya. In T. Pontillo \& M. P. Candotti (Eds.), Signless signification in ancient India and beyond (pp. 17-32). London and New York: Anthem Press.

Plato. (1951). Plato's Phaedo, F. J. Church (tr), New York: The Liberal Arts Press.

Popper, K. (1977). How i see philosophy. In A. Mercier \& M. Svilar (Eds.), Philosophers on their own work (Vol. 3). Berne and Frankfurt am Main: Peter Lang.

Raja, K. K. (1954). The theory of meaning according to the Buddhist logicians. Adyar Library Bulletin, $18(3-4), 178-195$.

Ramsay, H. (2005). Death part 3: Our attitude towards death. New Blackfriars, 86(1004), 418-424.

Ratnakīrti, (1957). Apohasiddhi. In A. Thakur (Ed.), Ratnakīrti-nibandhāval̄̄: Buddhist Nyāya works of Ratnakīti (pp. 58-66). Patna: Kashi Prasad Jayaswal Research Institute.

Rinpoche, S. (2008). The Tibetan book of living and dying, P. Gaffney, A. Harvey (eds). London: Rider, an imprint of Ebury Publishing of Random House Group Company.

Śāntarakșita, (2006). Tattvasamiraha (Vol. 1-2). Varanasi: Buddha Bharati.

Sasaki, G. H. (1992). Linguistic approach to buddhist thought. Delhi: Motilal Banarsidass Publishers.

Sharma, D. (1966). Epistemological negative dialectics of Indian logic-Abhāva versus Anupalabdhi. Indo-Iranian Journal, 9(4), 291-300.

Sharma, D. (1968). Buddhist theory of meaning (apoha) and negative statements. Philosophy East and West, 18(1-2), 3-10.

Sharma, D. (1969). The differentiation theory of meaning in Indian logic. Hague and Paris: Mouton \& Co. N. V. Publishers.

Shaw, J. L. (1978). Negation and the buddhist theory of meaning. Journal of Indian Philosophy, 6(1), 59-77.

Siderits, M., \& Katsura, S. (2013). Nāgārjuna's middle way: Mūlamadhyamaka-kārikāa. Boston: Wisdom Publications.

Siderits, M., Tillemans, T., \& Chakrabarti, A. (2011). Apoha: Buddhist nominalism and human cognition. New York: Columbia University Press.

Speranza, J. L., \& Horn, L. R. (2010). A brief history of negation. Journal of Applied Logic, 8(3), $277-301$.

Sugunasiri, S. H. J. (2011). “Asoulity” as translation of Anattā: Absence, not negation. Canadian Journal of Buddhist Studies, 7, 101-134.

Tripathi, C. L. (1977). The problem of 'negation' in Indian philosophy. Philosophy East and West, 27(4), $345-355$.

Van Houdt, J. (2011). The crisis of negation: An interview with Alan Badiou. Continent, 1(4), 234-248.

Yadav, B. S. (1977). Negation, Nirvāṇa, and nonsense. Journal of the American Academy of Religion, 45(4), 451-471.

Yao, Z. (2009). Empty subject terms in Buddhist logic: Dignāga and his Chinese commentators. Journal of Indian Philosophy, 37(4), 383-398.

Yeats, W. B. (1903). Aedh wishes for the cloths of heaven. In W. B. Yeats (Ed.), The wind among the reeds (p. 60). London: Elkin Matthews.

Publisher's Note Springer Nature remains neutral with regard to jurisdictional claims in published maps and institutional affiliations. 